\title{
Л.М. Гуніна
}

\section{Вплив сукцинату натрію на еритроцити за окисного стресу при фізичних навантаженнях}

\begin{abstract}
На основі модельних експериментів in vitro із застосуванням сукиинату натрію - основної складової дієтичної добавки "ЯнтарІн-Спорт" - доведено можливість корекції структурнофункиіонального стану мембран еритроцитів. Встановлено нормалізацію про- та антиоксидантного балансу еритроцитів зі зростанням вмісту відновленого глутатіону з 2,34 до 3,12 $10^{-12}$ ммоль $\cdot$ ep. $^{-1}$, а також зниження ӥхньої сорбиійної здатності (з 35,6 до 27,1\%) та проникності (з 4,61 до 3,98 ум. од). У дослідженнях іп vivo із застосуванням "ЯнтарІну-Спорт" підтверджено його позитивний вплив на еритроцитарні характеристики кваліфікованих спортсменів, що є підтрунтям для застосування похідних бурштинової кислоти для попередження спортивної анемії, поліпшення процесів мікроциркуляиії та збільшення швидкості кровообігу.

Ключові слова: сукцинат натрію, мембрани еритроиитів, окисний стресс, фізичні навантаження, спортивна анемія, дієтична добавка "ЯнтарІн-Спорт".
\end{abstract}

\section{ВСТУП}

Під час аеробної роботи працюючим м'язам спортсмена потрібне адекватне забезпечення їх киснем. Однією з основних складових киснетранспортної функції крові $\epsilon$ еритроцити, які саме й здійснюють перенесення кисню за рахунок молекули гемоглобіну. Зрілі еритроцити не здатні синтезувати білки; до того ж, вони втрачають мітохондрії, внаслідок чого не можуть метаболізувати піруват у циклі лимонної кислоти [17]. Тобто більшість метаболічних функцій, що властиві іншим клітинам організму, в зрілих еритроцитах відсутні $[13,20]$. Але еритроцити все ж таки $\epsilon$ метаболічно активними, і це допомагає їм виживати в кровообігу і виконувати свою основну функцію - транспорт кисню [16]. Для забезпечення адекватного метаболізму еритроцитів дуже важливою $є$ їхня плазматична мембрана, через яку, в основному, відбувається обмін речовин і енергії між червоною клітиною крові та яке її оточує

(C) Л.М. Гуніна середовищем $[18,20]$. Відповідно, різноманітні зсуви гомеостазу організму призводять до порушень структурно-функціонального стану мембран еритроцитів $[5,15]$.

За окисного стресу (OC), який викликано інтенсивними фізичними навантаженнями, в мембрані еритроцитів спостерігається конформація ліпід-білкового бішару 3 його ущільненням, що призводить до зниження трансмембранної функції та формування так званої “жорсткої” мембрани $[2,13,21]$. Зростання в’язкості цитозолю, особливо в примембранному шарі глікокаліксі, призводить до накопичення у мембрані високотоксичних продуктів обміну речовин, що проявляється змінами форми та розміру еритроцитів, зниженням здатності їх до деформації, появою аномальних за своїми агрегаційними властивостями клітин [23, 27]. Це супроводжується змінами реологічного стану крові, погіршенням мікроциркуляції та уповільненням тканинного кровообігу, що спричинює зниження оксигенації м'язів і функціо- 
нальних резервів спортсмена [2, 6, 10]. Структурно-функціональні перебудови еритроцитарної мембрани, викликані ОС при фізичних навантаженнях, призводять й до інших негативних гомеостатичних зрушень, зокрема, до виникнення тимчасової функціональної анемії, яка є однією 3 важливих причин погіршення працездатності спортсменів [2, 4, 6, 14, 27]. Кінцевою фазою перебудов в еритроциті може стати ериптоз (від англ. eryptosis) - клітинна смерть, яка програмується, та характеризується зменшенням об'єму еритроцитів, мембранним блебінгом, активацією протеаз і виходом фосфатидилсерину на зовнішню мембранну поверхню [7, 20]. Стресорними факторами, що можуть запустити ериптоз, $є$ різкі осмотичні зміни середовища, яке оточує клітини, ОС 3 виникненням про- та антиоксидантного дисбалансу, зменшення проникності кальційзалежних іонних каналів та виснаження енергетичних ресурсів клітин $[18,19]$.

Тому пошук шляхів покращання стану еритроцитів i, відповідно, структури та функції їхніх плазматичних мембран, $\epsilon$ дуже актуальним для попередження спортивної анемії та в подальшому - ериптозу. Одним 3 таких напрямків може бути використання речовин, які беруть участь в енергетичному обміні, і тому саме вони $є$ дуже важливими при інтенсивних фізичних навантаженнях $[16,25]$. Виходячи з цього, оптимальним було б дослідження зрушень змін стану мембран еритроцитів у спортсменів під впливом метаболітів циклу трикарбонових кислот, який є складовою процесу енергозабезпечення організму, i, в першу чергу, сукцинату (бурштинової кислоти). Саме тому за пропозицією співробітників лабораторії стимуляції працездатності та адаптаційних реакцій у спорті вищих досягнень НДІ НУФВСУ на основі натрієвої солі бурштинової кислоти вітчизняною фірмою ТОВ "СигмаПівдень" була створена дієтична добавка (ДД)
“ЯнтарІн-Спорт” (ЯС) (ТУ У 15.8.-20990275. 001-2001), проте їі властивості недостатньо досліджені.

Метою нашої роботи було визначення in vivo та in vitro впливу сукцинату натрію на біохімічні та структурні змін мембран еритроцитів в умовах ОС за інтенсивних фізичних навантажень.

\section{МЕТОДИКА}

Дослідження деяких показників гематологічного гомеостазу, біохімічних характеристик і функціональних властивостей еритроцитарних мембран проведені у 36 веслувальників на байдарках і каное під час тренувань 3 виконанням роботи аеробного характеру, з яких 20, що приймали ДД, склали основну групу, а решта 16 - контрольну. Середній вік спортсменів становив $(21,3 \pm 2,4)$ роки. За статтю (чоловіки), ростом, масою, віком, кваліфікацією вибірки спортсменів були репрезентативні. Також для порівняння гематологічні та біохімічні показники проаналізовано у 12 здорових нетренованих осіб (донори) відповідного віку та статі. Для проведення досліджень у спортсменів і донорів в стані спокою натщесерце брали кров 3 ліктьової вени (5 мл).

У дослідах in vivo за допомогою автоматичного гематологічного аналізатора “Erma-PCE 210” (“ERMA INC.”, Японія) тестували зміни під впливом ДД ЯС клітинного складу периферичної крові та еритроцитарних характеристик, а саме середньої кількості (MCH, від англ. Mean Corpuscular Hemoglobin) та середньої концентрації (МCHC, від англ. Mean Corpuscular Hemoglobin Concentration) гемоглобіну в еритроциті, середнього об'єму червоних кров'яних тілець (MCV, від англ. Mean Corpuscular Volume) і анізоцитозу як коефіцієнта варіації об'єму еритроцитів.

Для вивчення механізмів впливу різних метаболітів циклу Кребса (у вигляді 
натрієвих солей) на мембрани еритроцитів використовували зразки крові спортсменів тільки контрольної групи, які не приймали ДД. Ці 16 зразків крові було відповідно до використаного метаболіту циклу Кребса розподілено на 3 підгрупи (1-ша - 6 зразків, 2-га та 3-тя - по 5 зразків). До зразків крові 1-ї підгрупи додавали сукцинат натрію, 2-ї групи - малат натрію та до 3-ї - цитрат натрію.

Для проведення модельних досліджень з еритроцитами in vitro при вивченні впливу метаболітів циклу Кребса на зміни розміру еритроцитів і структурно-функціонального стану мембран червоних клітин зразок крові спортсмена розподіляли порівну. Одну частину застосовували як контроль і не додавали ніяких речовин. Усі досліджені речовини - сукцинат, малат і цитрат натрію додавали до решти зразка (2,5 мл) свіжезаготовленої стабілізованої гепарином крові до кінцевої концентрації 5 ммоль/л та інкубували протягом 30 хв при кімнатній температурі. Після інкубації зразків цільної крові спортсменів 3 метаболітами циклу Кребса досліджували структурно-функціональний стан мембран еритроцитів. Таким чином, ідентичні гематологічні та біохімічні дослідження були проведені зі зразками, крові, яку інкубували 3 дослідженими речовинами, та 3 інтактною кров'ю спортсменів. Аналогічні дослідження були проведені також зі зразками крові донорів, за виключенням інкубації 3 метаболітами циклу Кребса.

Для біохімічних досліджень застосовували суспензію еритроцитів, яку отримували після триразової обробки гіпотонічним розчином натрію хлориду $(0,65 \%) 3$ наступним центрифугуванням при 3000 хв$^{-1}$ протягом 10 хв. Потім осад еритроцитів відмивали від залишків плазми в 155 ммоль/л розчині натрію хлориду і центрифугували ще раз за тих самих умов [11]. У відмитих еритроцитах вивчали інтенсивність перекисного окиснення ліпідів (ПОЛ) за накопи- ченням ТБК-активних продуктів, вміст яких оцінювали спектрофотометрично за вмістом малонового діальдегіду (МДА) при довжинах хвиль 532 і 580 нм [1]. Антиоксидантну активність еритроцитів тестували за змінами вмісту відновленого глутатіону після інкубації еритроцитарної суспензії 3 реактивом Елмана, вимірюючи за довжини хвилі 412 нм оптичну густину утвореного продукту реакції (тіонітрофенильні аніони) [7].

Як показники функціонального стану мембран визначали сорбційну здатність еритроцитів за змінами поглинання вітального барвника метиленового синього, а також їхню проникність. Для оцінки цього показника 1 мл суспензії еритроцитів (вміст клітин був $4 \cdot 10^{7}$ ) змішували 33 мл розчину вітального барвника метиленового синього (“Chemapol”, Чехія, 0,002 \% на ізотонічному розчині натрію хлориду), інкубували 10 хв при кімнатній температурі та центрифугували 10 хв при 3000 хв$^{-1}$. Оптичну густину вихідного розчину та надосадової рідини визначали при довжині хвилі 630 нм в одиницях екстинкції відносно ізотонічного розчину [12]. Проникність еритроцитів досліджували, як описано в праці Михайловича та співавт. [9].

Для характеристики густини глікокалікса еритроцитів визначали його сорбційну ємність змішуванням 1 мл суспензії еритроцитів (4 $\cdot 10^{7}$ клітин) 33 мл розчину барвника альціанового синього ("Bio-Optiса", Італія, 0,005 \% на ізотонічному розчині натрію хлориду). Суміш інкубували при 18$21{ }^{\circ} \mathrm{C}$ і центрифугували протягом 10 хв при 1000 хв$^{-1}$. Вимірювали концентрацію барвника в надосадовій рідині при $\lambda=617$ нм, використовуючи як контроль ізотонічний розчин [11].

Отримані результати обробляли статистично з використанням прикладного пакету програм Excel 97 і ліцензованої програми GraphPad InStat. Для оцінки достовірності різниці застосовували критерій t Стьюдента. Малі вибірки аналізували із застосу- 
ванням непараметричного критерію Вілкоксона.

\section{РЕЗУЛЬТАТИ ТА ЇХ ОБГОВОРЕННЯ}

У гематологічних дослідженнях in vivo було показано, що існують достовірні відмінності між середнім об'ємом еритроцитів і ступенем їхнього анізоцитозу в здорових нетренованих осіб і кваліфікованих спортсменів (рисунок). Інтенсивні фізичні навантаження призводять до зменшення MCV i, відповідно, до підвищення анізоцитозу. Це пояснюється змінами про- та антиоксидантного балансу в мембранах еритроцитів внаслідок хронічного ОС при фізичних навантаженнях [2, 4, 23, 26, 27] та, на нашу думку, на першому етапі $€$ проявом пристосувальних реакцій з боку системи червоних кров'яних тілець.

Водночас результати гематологічного аналізу свідчать, що у спортсменів курсове застосування ДД ЯС протягом 21 доби на фоні інтенсивних фізичних навантажень призводить до певних позитивних змін як клітинного складу крові, так й еритроцитарних індексів, зокрема МСH, MCHC,

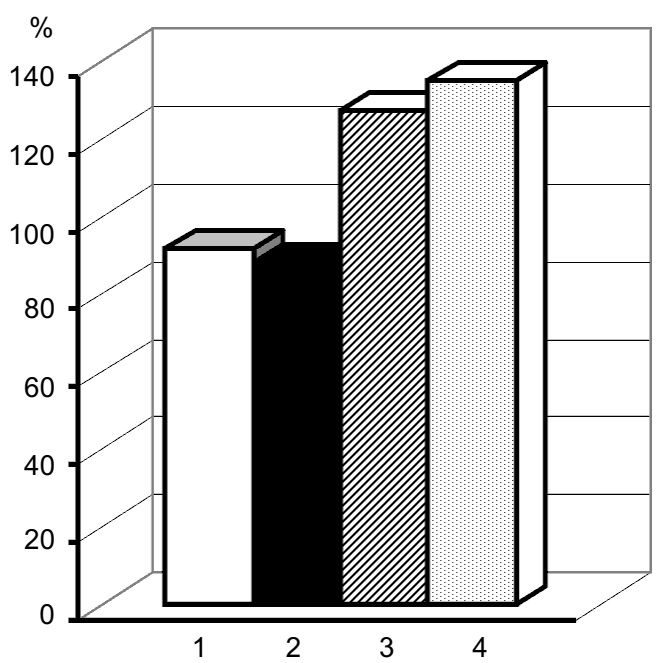

Вплив аеробної роботи на розмір еритроцитів у відсотках щодо значень у донорів: 1,2 - середній об'єм еритроцитів in vivo та in vitro відповідно, 3, 4 анізоцитоз in vivo та in vitro відповідно
$\mathrm{MCV}$, порівняно зі значеннями у спортсменів контрольної групи та референтними значеннями для веслувальників (табл. 1).

Встановлене під впливом ЯС зниження $\mathrm{MCV} є$ особливо важливим для процесів мікроциркуляції та, відповідно, швидкості кровообігу, оскільки макроцити (клітини 3 великим об'ємом) здатні уповільнювати швидкість потоку крові [29]. Достовірні зміни вмісту еритроцитів, які свідчать про прискорення еритропоезу під час фізичних навантажень, також вказують на позитивний вплив ЯС на гематологічний гомеостаз.

У модельному експерименті in vitro було встановлено, що у спортсменів, порівняно 3 донорами, середній об'єм еритроцитів знижується, хоча й не суттєво; при цьому анізоцитоз збільшується, тобто в загальному пулі з'являються клітини різного, як більшого, так і меншого, за нормальні, розміру (див. рисунок). При інкубації стабілізованої крові спортсменів з метаболітами циклу Кребса встановлено, що найбільшу дію на розмір еритроцитів має сукцинат натрію (табл. 2). Анізоцитоз знижується залежно від інкубаційного середовища: більш істотні зміни, порівняно 3 контролем, відбуваються при інкубації 3 сукцинатом натрію, а мінімальні - 3 цитратом натрію. Це збігається 3 даними відносно усереднення об'єму еритроцитів під впливом ДД на основі сукцинату натрію, що цілком логічно призведе до покращення їх просування по мікросудинам, i, відповідно, киснетранспортної функції крові [28].

Результати модельного експерименту свідчать, що регулярні фізичні навантаження аеробного характеру призводять до активації процесів ПОЛ у мембранах еритроцитів (вміст МДА зростає на 25,4 \%) 3 одночасним компенсаторним підвищенням вмісту відновленого глутатіону (табл. 3). Накопичення продуктів ПОЛ в еритроцитах призводить до змін їхньої проникності, сорбційної здатності та сорбційної ємності глікокалікса, тобто 
Л.М. Гуніна

Таблиця 1. Зміни показників гематологічного гомеостазу та еритроцитарних характеристик у спортсменів за

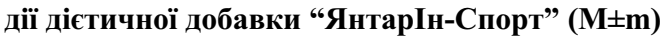

\begin{tabular}{|c|c|c|c|}
\hline \multirow[t]{2}{*}{ Показники } & \multicolumn{2}{|c|}{ Групи спортсменів } & \multirow{2}{*}{$\begin{array}{c}\text { Референтні } \\
\text { значення }\end{array}$} \\
\hline & контрольна & основна & \\
\hline Вміст еритроцитів, $10^{12} \cdot \pi^{-1}$ & $4,76 \pm 0,22$ & $5,47 \pm 0,14^{*}$ & $3,86-5,03$ \\
\hline Вміст гемоглобіну, г $\cdot л^{-1}$ & $141,8 \pm 7,5$ & $159,7 \pm 6,5$ & $124,8-167,13$ \\
\hline Гематокрит, \% & $34,7 \pm 3,6$ & $41,8 \pm 4,2$ & $38-50$ \\
\hline Середній об’єм еритроцитів, фл & $88,5 \pm 4,8$ & $74,7 \pm 3,1 *$ & $79-88$ \\
\hline Середня кількість гемоглобіну в еритроциті, пг & $35,4 \pm 0,6$ & $40,8 \pm 0,4 *$ & $24-32$ \\
\hline Середня концентрація гемоглобіну в еритроциті, г · дл ${ }^{-1}$ & $27,4 \pm 2,1$ & $34,6 \pm 1,7^{*}$ & $30-38$ \\
\hline Анізоцитоз, \% & $17,82 \pm 0,24$ & $14,3 \pm 0,12 *$ & до 14 \\
\hline
\end{tabular}

*P $<0,05$ порівняно зі значеннями у спортсменів контрольної групи

функціональних характеристик мембран. Це підтверджують отримані раніше нами та іншими дослідниками дані, які говорять, що за ОС при інтенсивних фізичних навантаженнях деформується мембрана еритроцитів і змінюються її властивості [4, 6, 30, 31].
Під впливом досліджених метаболітів циклу Кребса - сукцинату і малату натрію, але не цитрату, достовірно знижується інтенсивність ПОЛ в еритроцитах та їхня проникність відносно вихідного рівня аналогічних показників у спортсменів (див.

Таблиця 2. Вплив метаболітів циклу Кребса на розмір еритроцитів в модельному експерименті (М $\pm m)$

\begin{tabular}{l|l|l}
\hline Умови дослідження & $\begin{array}{l}\text { Середній об’єм } \\
\text { еритроцитів, фл }\end{array}$ & Анізоцитоз, \% \\
\hline 1-ша підгрупа (додавання сукцинату натрію) & $71,91 \pm 1,04$ & $13,01 \pm 0,27$ \\
2-га підгрупа (додавання малату натрію) & $74,86 \pm 1,21^{*}$ & $15,34 \pm 0,28^{*}$ \\
3 -тя підгрупа (додавання цитрату натрію) & $74,26 \pm 1,17^{*}$ & $16,66 \pm 0,31^{*}$
\end{tabular}

*P $<0,015$ порівняно зі значеннями у 1 -й підгрупі.

табл. 3). Причому ці зміни найбільш виражені при інкубації еритроцитарної суспензії 3 сукцинатом натрію.

Існують дані відносно протекторної дії сукцинату і малату натрію на мембрани мітохондрій за інтенсивних фізичних навантажень [25]. Такий вплив може бути пояснений енергізацією мітохондріальних

Таблиця 3. Вплив метаболітів циклу Кребса на біохімічні показники і параметри структурно-функціонального стану мембран еритроцитів в модельному експерименті (M $\pm \mathbf{m})$

\begin{tabular}{|c|c|c|c|c|c|}
\hline \multirow[b]{2}{*}{ Показники } & \multirow[b]{2}{*}{ Донори } & \multirow[b]{2}{*}{ Контроль } & \multicolumn{3}{|c|}{ Спортсмени } \\
\hline & & & \begin{tabular}{|c|}
$1-ш а$ \\
підгрупа \\
(додавання \\
сукцинату \\
натрію)
\end{tabular} & $\begin{array}{c}\text { 2-га } \\
\text { підгрупа } \\
\text { (додавання } \\
\text { малату } \\
\text { натрію) }\end{array}$ & $\begin{array}{c}\text { 3-тя } \\
\text { підгрупа } \\
\text { (додавання } \\
\text { цитрату } \\
\text { натрію) }\end{array}$ \\
\hline Малоновий діальдегід, нмоль · $10^{6}$ ер. & $3,67 \pm 0,10$ & $4,61 \pm 0,15^{*}$ & $3,98 \pm 0,06^{* *}$ & $4,21 \pm 0,08^{*, * *}$ & $4,58 \pm 0,09^{*}$ \\
\hline Відновлений глутатіон, $10^{-12}$ ммоль · ep..$^{-1}$ & $1,65 \pm 0,10$ & $2,34 \pm 0,12^{*}$ & $3,12 \pm 0,09^{* * *}$ & $2,28 \pm, 12^{*}$ & $2,31 \pm 0,16^{*}$ \\
\hline Сорбційна здатність еритроцитів, \% & $21,6 \pm 2,4$ & $35,6 \pm 1,2^{*}$ & $27,1 \pm 1,7 * * *$ & $31,6 \pm 1,1^{*}$ & $33,2 \pm 1,6^{*}$ \\
\hline Проникність мембрани еритроцитів, ум. од. & $3,67 \pm 0,10$ & $4,61 \pm 0,15^{*}$ & $3,98 \pm 0,06^{* *}$ & $4,21 \pm 0,08^{* * *}$ & $4,58 \pm 0,09^{*}$ \\
\hline Сорбційна ємність глікокалікса, пг · ер..$^{-1}$ & $1,82 \pm 0,12$ & $3,11 \pm 0,09^{*}$ & $1,96 \pm 0,07^{* *}$ & $2,78 \pm 0,05^{* * *}$ & $3,12 \pm 0,08^{*}$ \\
\hline
\end{tabular}

*P<0,01 порівняно з еритроцитами донорів; **P $<0,05$ порівняно 3 контролем. 
мембран внаслідок утилізації цих метаболітів у циклі трикарбонових кислот $[8,31]$. Підвищення енергетичного балансу клітин у цілому опосередковано впливає на інші мембранні структури, про що свідчить зменшення гіперферментемії [24, 27]. Умови нашого експерименту 3 відмитими еритроцитами спортсменів виключають такий механізм дії досліджуваних метаболітів, оскільки в цих клітинах відсутній цикл Кребса.

Відомо, що жорсткість мембран еритроцитів і порушення їхного розміру та форми значною мірою залежить від виснаження в них запасів АТФ $[5,13,22]$. Можна припустити, що в організмі спортсменів при активізації енергетичного обміну під час фізичних навантажень саме через накопичення внутрішньоклітинного АТФ здійснюється вплив на функціональний стан мембран еритроцитів і, відповідно, на зміни рівня анізоцитозу внаслідок зростання кількості дискоїдів-нормоцитів, що не суперечить даним літератури, отриманим за інших умов дослідження, наприклад при серпоподібноклітинній анемії $[17,28]$. Але, враховуючи, що наше дослідження було проведено на попередньо відмитих еритроцитах, слід думати й про інші шляхи впливу ЯС на еритроцитарну мембрану. До речі, отримані результати не можна пояснити опосередкованою дією метаболітів через інші формені елементи крові, тому що умови дослідження це теж виключають. Тому, певно, їх слід розглядати як наслідок безпосередньої дії вивчених метаболітів на ізольовані еритроцити за умов хронічного OC. Результати дослідження свідчать про прямий стабілізувальний вплив сукцинату i, меншою мірою, малату натрію, на еритроцитарну мембрану, що відображується зрушенням про- та антиоксидантного балансу (тобто змінами вмісту МДА і відновленого глутатіону), а також сорбційної здатності та проникності еритроцитів, зменшенням їхнього анізоцитозу тощо. Найбільш активним серед досліджених метаболітів циклу Кребса в цьому відношенні є сукцинат.

Результати нашої роботи підтверджують зміни стану мембран еритроцитів, виявлені нами раніше за хронічного ОС при злоякісних новоутвореннях [3]. Слід відмітити, що встановлені мембраностабілізувальні властивості сукцинату натрію відносно еритроцитів спортсменів за ОС при інтенсивній аеробній роботі подібні до змін, що викликає й ОС іншого генезу, наприклад, при опроміненні [8].

Щодо механізму дії ЯС і, відповідно, сукцинату натрію (i, можливо, малату натрію), то одержані нами у спортсменів результати узгоджуються 3 висунутою у праці [3] гіпотезою про утворення полярних ковалентних зв'язків між негативнозарядженими карбоксилами дикарбонової кислоти і позитивно зарядженими атомами азоту суміжних гідрофільних головок фосфоліпідів плазматичної мембрани. Утворені таким чином “скобки” сприяють стабілізації мембрани. Геометрія молекулярної структури сукцинату натрію (основної складової ЯС) і фосфоліпідів мембрани не суперечить можливості утворення таких надмолекулярних комплексів.

Існують й інші механізми впливу вивчених метаболітів на мембрану еритроцитів у спортсменів. Гальмування накопичення МДА в нашому дослідженні свідчить про зниження активності ПОЛ, що корелює 3 упорядкуванням подвійного ліпідного шару в мембранах і призводить до нормалізації їхнього функціонального стану [21, 29]. Раніше також було встановлено, що сукцинат та його похідні здатні інгібувати ПОЛ [24, 31]. Можливо, що отримані нами результати можуть бути пояснені зв'язком, що виникає між молекулами сукцинату та фосфатидилсеринів, які за гіпероксидації 3'являються на зовнішній поверхні клітинної мембрани [20], та стабілізують їі. Це має відношення до попередження ериптозу, який може виникати у спортсменів за понадінтенсивних і тривалих фізичних навантажень 
та зумовлений тим, що за виразного ОС АТФ-залежні фліпази, що у фізіологічних умовах переносять фосфатидилсерини на цитозольний бік мембрани, перестають функціонувати [13].

Відомо, що у спортсменів під час інтенсивних фізичних навантажень поліпшення структурно-функціонального стану мембран еритроцитів сприяє підвищенню їх осморезистентності та здатності до деформування, збільшенню стійкості до ОС i протидіє розвитку спортивної анемії, яка є характерною для навантажень під час тренувань і змагань, покращує агрегаційні властивості еритроцитів, прискорюючи швидкість кровообігу $[2,4,22]$. Усі вищезазначені зміни структурно-функціонального стану мембран еритроцитів позитивно впливають на показники фізичної працездатності [21, 25, 29, 31].

Таким чином, отримані в нашому дослідженні in vitro та in vivo результати висвітлюють один 3 можливих тонких механізмів стабілізувального впливу метаболітів циклу Кребса на мембрани еритроцитів. Тому вони є підгрунтям доцільності застосування сукцинату натрію і засобів на його основі (ДД ЯС, Янтавит, Енерліт, Метавіт; лікарських препаратів мексидол, мексикор, лимонтар тощо) у складі схем фармакологічної підтримки тренувального процесу для попередження розвитку негативних явищ, пов'язаних з виникненням спортивної анемії та наступного ериптозу, зростанням агрегації еритроцитів, уповільненням транспорту кисню та, відповідно, погіршенням фізичної працездатності спортсменів.

\section{Л.М.Гунина}

\section{ВЛИЯНИЕ СУКЦИНАТА НАТРИЯ НА ЭРИТРОЦИТЫ ПРИ ОКСИДАТИВНОМ СТРЕССЕ, ОБУСЛОВЛЕННОМ ФИЗИЧЕСКИМИ НАГРУЗКАМИ}

На основе модельных экспериментов in vitro с применением сукцината натрия - основной составляющей диетической добавки “ЯнтарИн-Спорт" - доказана возможность коррекции структурно-функционального состояния мембран эритроцитов. Установлена нормализация прооксидантно-антиоксидантного баланса отмытых эритроцитов с накоплением в них восстановленного глутатиона (с 2,34 до 3,12 $10^{-12}$ ммоль $\cdot$ эр.- ${ }^{-1}$ ), а также снижение их сорбционной способности (с 35,6 до 27,1 \%) и проницаемости (с 4,61 до 3,98 усл. ед.). В исследованиях in vivo подтверждено позитивное влияние сукцината натрия на эритроцитарные характеристики у квалифицированных спортсменов, что является основанием для применения производных янтарной кислоты с целью предупреждения спортивной анемии, улучшения процессов микроциркуляции и увеличения скорости кровотока.

Ключевые слова: сукцинат натрия, мембраны эритроцитов, оксидативный стресс, физические нагрузки, спортивная анемия, диетическая добавка “ЯнтарИн-Спорт”.

\section{L.M. Gunina}

\section{AN INFLUENCE OF SODIUM SUCCINATE ON ERYTHROCYTES AT OXIDATIVE STRESS UNDER PHYSICAL LOADING}

On the basis of model experiments in vitro with application of sodium succinate which is the basic constituent of dietary supplementation "YantarIn-Sport", possibility of correction of the structurally-functional state of red blood cell membranes is well-proven. It is show that prooxidative-antioxidative balance in washed erythrocytes is normalized with the accumulation of recovered glutathione from 2,34 to $3,12 \cdot 10^{-12} \mathrm{mM}$ in one erythrocyte, and their sorption ability (from 35,6 to $27,1 \%$ as well as red blood cells permeability (from 4,61 to 3,98 conditional units) are decreased. In vivo research the positive influence of sodium succinate on descriptions of red blood cells of skilled sportsmen is confirmed, that is founding for application of succinic acid derivatives with the purpose of sporting anaemia' warning as well as improvement of microcirculation processes and increase of speed blood flow.

Key words: sodium succinate, erythrocyte membranes, oxidative stress, physical loading, sporting anaemia, dietary supplement "YantarIn-Sport".

Science Institute of National University of Physical Education and Sport of Ukraine, Kyiv

\section{СПИСОК ЛІТЕРАТУРИ}

1. Банкова В.В., Прищепова Н.Ф., Авратинский О.И. Способ оценки патологических изменений плазматической мембраны у детей при различных заболеваниях // Патол. физиология и эксперим. терапия. 1987. - №3. - C.78-81.

2. Гунина Л.М., Гуменюк Р.С., Парфенюк Н.С., Конончук Е.Н. Влияние коррекции гематологических показателей на физическую работоспособность спортсменов // Спорт. медицина. - 2009. № 1-2. - C.11-16. 
3. Гуніна Л.М., Малюк В.І., Войціцька Т.В. Вплив метаболітів циклу трикарбонових кислот на структурно-функціональний стан мембран еритроцитів у хворих на рак шлунка // Проблеми екол. та мед.генетики і клін. імунології: Зб. наук. праць. К.-Луганськ-Харків. - 2001. - Вип. 4 (36). - С.109-117.

4. Гуніна Л.М., Олійник С.А., Іванов С.В. Зміни показників крові та прооксидантно-антиоксидантного балансу в мембранах еритроцитів при інтенсивному фізичному навантаженні // Мед. хімія. 2007. - 9, № 1. - С.91-97.

5. Гуніна Л.М., Орел В.С., Савоста А.В., Тимченко А.С. Поверхнева архітектоніка цитоскелету еритроцитів у нормі та при метаболічних зрушеннях в організмі // Укр. журн. гематології та трансфузіології. - 2008. - № 2. - С.5-13.

6. Гуніна Л.М. Роль профілактики та корекції функціональної анемії у підвищенні фізичної працездатності спортсменів // Фізіол. журн. - 2007. 53, № 4. - С. 91-97.

7. Зайцев В.Г., Закревский В.И., Давыдов А.И. Уровень гипергликемии у больных сахарным диабетом // Клін. лаб. діагностика. - 1999. - № 11. C.32-33.

8. Малюк В.И. Малые дозы ионизирующих излучений: фармакологические подходы к профилактике и коррекции. - В кн.: Медицинские последствия аварии на Чернобыльской атомной станции. - Ч. 3 / Под ред. М.И. Руднева. - К.: Наук. думка, 1999. С. $192-198$.

9. Михайлович В.А., Марусанов В.Е., Бичун А.Б. Проницаемость эритроцитарной мембраны и ее сорбционная способность - оптимальные критерии тяжести эндогенной интоксикации // Анестезиология и реаніматологія. - 1993. - № 5. - С.66-69.

10. Новиков В.С., Шустов Е.Б., Горанчук В.В. Коррекция функциональных состояний при экстремальных воздействиях. - С.-Птб: Наука, 1998. - С. 383-393.

11. Семко Г.А. Структурно-функциональные изменения мембран и внешних примембранных слоев эритроцитов при гиперэпидермопоэзе // Укр. биохим. журн. - 1998. - 70, №3. - С.113-118.

12. Тогайбаев А.А., Кургузкин А.В., Рикун И.В. Способ диагностики эндогенной интоксикации // Лаб. дело. - 1988. - №9. - С.22-24.

13. Bordbar A., Jamshidi N., Palsson B.O. A proteomically derived knowledge-base of erythrocyte metabolism that can be used to simulate its physiological and pathophysiological states // BMC Syst. Biol. - 2011. - 5, № 1. - P. 110-118.

14. Erslev A.I. March hemoglobinuria, sports anemia and other space anemia. - Williams hematology. VI Edition / Eds. Beutler E. - Washington: McGraw-Hill, 2001. P. 627-628.

15. Gunina L.M., Oliynyk S.A. The effect of Rithmocor on the state of erythrocyte membranes and athlete's adaptation to intensive training loads // Abstr. of the I- th Baltic conf. in exercise and sports sciences and the I-th Baltic conference of young scientists in exercise and sports sciences, 7-10 May 2008, Tartu, Estonia / Eds. T. Jürimäe, M. Pääsuke, J. Jürimäe // Acta Kinesiol. Univ. Tartuensis. - 2008. - 13 (Suppl.). P. 100-101.

16. Koivunen P., Hirsilд M., Remes A.M. Inhibition of hypoxia-inducible factor (HIF) hydroxylases by citric acid cycle intermediates: possible links between cell metabolism and stabilization of HIF // J. Biol. Chem. 2007. - 282, № 7. - P. 4524-4532.

17. Lang K.S., Roll B., Myssina S., Schittenhelm M. Enhanced erythrocyte apoptosis in sickle cell anemia, thalassemia and glucose-6-phosphate dehydrogenase deficiency // Cell Physiol. Biochem. - 2002. - № 12. P. 365-372.

18. Lang K. S., Duranton C., Poehlmann H., Myssina S. Cation channels trigger apoptotic death of erythrocytes // Cell Death and Differentiation. - 2003. - № 10. P. 249-256.

19. Lang K.S., Myssina S., Brand V. Involvement of ceramide in hyperosmotic shock-induced death of erythrocytes // Cell Death Differ. - 2004. - № 11. P. 231-243.

20. Manno S., Takakuwa Y., Mohandas N. Modulation of Erythrocyte Membrane Mechanical Function by Protein 4.1 Phosphorylation // J. Biol. Chem. - 2005. 280, № 4. - P. 7581-7587.

21. Mastaloudis A., Morrow J.D., Hopkins D.W. et al. Antioxidant supplementation prevents exercise-induced lipid peroxidation, but not inflammation, in ultramarathon runners // Free Rad. Biol. and Med. 2004. - 36, Issue 10. - P. 1329-1341.

22. Mikhalyov I., Samsonov A. Lipid raft detecting in membranes of live erythrocytes // Biochim. Biophys. Acta. - 2011. - 1808, № 7. - P. 1930-1939.

23. Miller M.W., Miller M.W., Battaglia L.F. Biological and environmental factors affecting ultrasound-induced haemolysis in vitro: 3. Antioxidant (Trolox $\left.{ }^{\circledR}\right)$ inclusion // Ultrasound Med. and Biol. - 2003. - 29, Issue 1. - P. 103-112.

24. Nguyen E., Picklo M.J. Inhibition of succinic semialdehyde dehydrogenase activity by alkenal products of lipid peroxidation // Biochim. Biophys. Acta. 2003. - 1637, № 1. - P. 107-112.

25. Repetskaya A.G., Malyuk V.I. Sodium succinate strentchens in the rat mitochondrial membrane on intensive training load in experiment // J. Int. Fed. Med. Biol. Engineering. - 2007. - 45. - P. 119-123.

26. Rojas C., Cadenas S., Lypez-Torres M. Increase in heart glutathione redox ratio and total antioxidant capacity and decrease in lipid peroxidation after vitamin E dietary supplementation in guinea pigs // Free Rad. Biol. and Med. - 1996. - 21, Issue 7. - P. 907-915.

27. Satoshi S., Kiyoji T., Hiroyo K., Fumio N. Exerciseinduced lipid peroxidation and leakage of enzymes before and after vitamin E supplementation // Int. J. 
Biochem. - 2009. - 45, Issue 8. - P.835-838.

28. Schwarz S., Haest C.W., Deuticke B. Extensive electroporation abolishes experimentally induced shape transformations of erythrocytes: a consequence of phospholipid symmetrization? // Biochim. Biophys. Acta. - 1999. - 1421, № 2. - P. 361-379.

29. Senturk U.K., Yalcin O., Gunduz F. et al. Effect of antioxidant vitamin treatment on the time course of hematological and hemorheological alterations after an exhausting exercise episode in human subjects // J. Appl.

НДІ Наи. ун-ту фіз. виховання і спорту України, Київ E-mail: gunina-sport@yandex.ru
Physiol. - 2005. - 98. - P. 1272-1279.

30. Stouns R., Redisson D.J., Ninessi A. Red Blood Cell Indices: Implications for Practice: Erythrocyte Structure and Function // Blood. - 2009. - 114, № 21. P. 431-442.

31. Vengerovski- A.I., Khazanov V.A. Effects of silymarin and its combination with succinic acid on brain bioenergetics in rats with experimental inhibition of betaoxidation of fatty acids // Eksp. Klin. Farmakol. - 2007. 70, № 2. - P. 51-55. 